\title{
Supplicants \& Guardians: the petitions of Royalist widows during the Civil Wars and Interregnum, 1642-1660
}

Hannah Worthen ${ }^{1}$

During the Civil Wars and Interregnum Parliament sought to fund their war effort by confiscating Royalist estates. The widows of Royalist landowners were left without a husband and without the prospect of any means of support unless they could regain those lands. These women petitioned Parliament alongside Royalist men in the interests of themselves and their families. They used emotive language of distress, sophisticated knowledge of their entitlement to inherited lands as well as accounts of their husband's actions and their own assertions of loyalty. The petitions of Royalist widows remind us that women throughout history had the capacity to respond to the realities and aftermath of war with tenacity and resilience.

The Civil Wars of the mid-seventeenth century in Britain produced widows in large numbers on both sides of the conflict. Between 1642 and 1652 Parliamentarian and Royalist soldiers participated in wars that caused profound changes to both the nature of government and the lives of ordinary communities and families. Casualty numbers are disputed but one historian estimates that perhaps as many as $7 \%$ of the population of the three kingdoms of England, Ireland and Scotland were killed in battle, by disease or accident. ${ }^{1}$ Combat always carries both a human and material cost and during these years lives were lost, homes destroyed and fortunes changed. The term 'home front' is not frequently applied to studies of these particular wars and yet historians of other periods have fruitfully analysed the experience of women left behind who fought their own form of battles. ${ }^{2}$ Analysing the home front seems particularly apt as a methodology in the case of civil war. ${ }^{3}$ These conflicts, by their very nature, resulted in a profound overlapping of the military and domestic experience.

Both Parliamentarians and Royalists sought to recoup some of the huge costs of war by confiscating the estates of their enemies and taking the profits to fund their armies. Royalist widows petitioned the Parliamentarian administration asking for the return of their estates and those records can now be found at The National Archives. These documents have already proved to be a valuable source for enriching our understanding of early modern

\footnotetext{
${ }^{1}$ Hannah Worthen is a Collaborative Doctoral Partnership PhD candidate at the University of Leicester and The National Archives. She is working on the experience of war widows during the mid seventeenth century. This work was supported by the Arts and Humanities Research Council under Grant number AH/L008793/1. Correspondence to: 47A Norman Road, Canterbury, CT13LX. Email: hw189@le.ac.uk
} 
perceptions of loyalty but the petitions of women have yet to be studied. ${ }^{4}$ This paper seeks to redress that by specifically examining the narratives of widows and analysing the ways in which they framed and fashioned themselves through the medium of the petition in order to defend their lands on behalf of themselves and their children. These women participated in the struggles of the wartime home front by skilfully engaging with a political process that had been imposed upon them by the events of the period.

During the years of conflict Parliamentary committees in Westminster multiplied. Two in particular concerned Royalist landowners: the Sequestration Committee, which initially dealt with the confiscated estates of Royalists, and the Committee for Compounding with Delinquents. ${ }^{5}$ The latter soon overtook the former as compounding, the process by which Royalists could regain their estates for a fee, proved to be an even more lucrative means of ready finance for the Parliamentarians. Estates were to be compounded for at two years' of their estimated value before the war in variable proportions ranging from two thirds to one tenth. The estates of soldiers and others in England not worth $£ 200$, or $£ 100$ in Scotland, were to be discharged without a fine. ${ }^{6}$ The process of identifying, managing and collecting the rents from sequestered estates lay with the county and most of them set up sequestration sub-committees. Many Royalist estates were discovered by informers who were rewarded accordingly. Some of the informers were Parliamentarian war widows and so in these cases this system set widows of both sides against each other. ${ }^{7}$ Those whom the Parliamentarians had deemed to be 'delinquent' travelled to Westminster throughout the period seeking to regain their estates. Delinquents were initially described as those who 'have been the causers or Instruments of the publike calamities' but Parliament came to more broadly include any who had born arms against them or contributed financially to the King's cause. ${ }^{8}$ In the case where the male landowner was deceased then it was his wife who had to present herself on behalf of her family's interests. That process began with the drafting of a petition.

Women who were active in supposedly public, male and political contexts in the early modern period have been the subject of recent historical research and interest. ${ }^{9}$ Tim Stretton has studied how women interacted with the legislative process in the Elizabethan period and found that 'the central courts at Westminster regularly processed cases involving knowledgeable women who were neither submissive nor deferential'. ${ }^{10}$ The genre of the petition seems to have afforded women particular opportunity. Alison Thorne has argued that despite the restrictions on women participating in political affairs it was still socially 
acceptable for them to intervene in the patronage system in an unofficial way. She investigates the letters of petition that were submitted by women on behalf of the disgraced male members of their family. The language of deference required in such a form particularly suited, and possibly benefited, the female supplicant. ${ }^{11}$ Women were able to frame their petitions in terms of helplessness while also skilfully using this rhetoric to advance their case. ${ }^{12}$ Elizabeth Lilburne, wife of the prominent Leveller campaigner John Lilburne, petitioned in this manner in 1659 when she presented her pleas to Richard Cromwell. ${ }^{13}$ Ann Hughes urges caution, however, before assuming petitions such as these represented a 'dramatic assertion of female political rights'. ${ }^{14}$ Conservative ideas about the correct role of a woman within the household were fundamental to Leveller perceptions of gender.

There was for Leveller wives and other participants in high profile petitioning campaigns a tension between deference and assertiveness, between upholding traditional societal values and participating in political narratives in novel ways. ${ }^{15}$ A study of Royalist widows can enrich these fields of research and indicate how women from across society experienced the war. They petitioned the Committees for Compounding and Sequestration in considerable numbers during the 1640s and 1650s. This survey includes 167 cases from the records of both committees as well as the Committee for the Advance of Money (which saw some overlap in business). ${ }^{16}$ The widows came from far across the country to present their case, which Table 1 demonstrates. Elizabeth Cotton, for example, complained to the Committee of Sequestrations that she had had to travel 140 miles to London. ${ }^{17}$ The regional spread of petitioners also shows that there were a high proportion of widows who came from areas initially largely controlled by the Royalists, for example the north of England.

The earliest petitions were sent in 1643 when Parliament was beginning to confiscate estates and were still being presented as late as 1659 in response to the sequestration imposed on Royalists involved in the various uprisings of the 1650s. However, the main bulk of the petitions came in the middle of the period as Figure 1 demonstrates. The first peak in activity in 1646 was probably the consequence of Royalists surrendering in the closing stages of the first civil war. The second peak in 1651 corresponds with a series of fresh legislation passed by Parliament in the early 1650 s to better order and centralise the process. ${ }^{18}$

The petitions were not written by the widows themselves. Furthermore, most of these widows would almost certainly have been given advice about the construction of their petitions. This could have been from a relative, a lawyer employed by their family, or the 
clerk who was penning it for them. ${ }^{19}$ Despite this women were engaging in the process of composing these petitions and presumably paying a fee for them to be written on their behalf. One hundred and two of the women signed their names and a further ten put down their mark upon their petitions. This may seem surprising given that David Cressy's study on literacy found that 'women were almost universally unable to write their own names for most of the sixteenth and seventeenth centuries'. ${ }^{20}$ However, Cressy did not differentiate between different classes of women (he clusters them with the most illiterate group of men) but does acknowledge the connection between wealth and literacy. ${ }^{21}$ Many of these women were from the gentry or aristocracy and so may have received some form of education as part of their upbringing. This was particularly important because they could be called upon to manage their estates as wives when their husbands were absent or as widows on behalf of their children. $^{22}$

Aside from using these signatures as an indicator of women's literacy it remains interesting that such a high percentage of widows chose to mark down or sign their own name if they were able. Many of these petitions also contain a wide variety of unique and persuasive as well as formulaic elements which suggest the influence of a distinctive authorial voice. Natalie Zemon Davies' work on French pardon tales in the sixteenth century suggested that historians should do more than just seek historical truth from the archives. She argued that 'the shaping choices of language, detail, and order are needed to present an account that seems to both writer and reader true, real, meaningful, and/or explanatory'. ${ }^{23}$ Consequently, the possibly fictitious elements created in the construction of these petitions can be revealing to historians. It is possible to argue, as Stretton has, that following this line of reasoning means that the issue of authorship becomes diminished. The focus then is on the story-telling rather than the story-teller 'or the factual integrity of the story'. ${ }^{24}$

Consequently, these documents have primarily been approached with a qualitative approach in order to learn more about the ways in which female petitioners fashioned themselves during the Civil War period. The intention has not been to discover the 'truth' of their assertions or to enhance our understanding of the realities of civil war life (although there are many glimpses of that). These petitions formed part of a survival strategy and the widows who constructed them were trying to regain their livelihoods and inheritance. Consequently, they have been analysed for what their contents can tell us about the knowledge, aims and narrative techniques of the women who wrote them. There are some problems with such an approach beyond the issue of authorship that has already been 
discussed. Ann Hughes' work on the Parliamentary Indemnity Committee has suggested that the language used in petitions to the State was shaped by the expectations of those who heard them. ${ }^{25}$ Also, many of the widows did not attempt to persuade the Committee but presented short and simple petitions asking for their lands back. Nevertheless, these women, alongside those who presented longer petitions, by the very act of petitioning were fashioning themselves as humble supplicants and defenders of their estates. Participating in this political process highlighted the inevitable tension between these two roles.

Research on these petitions has illuminated three key strategies by which widows attempted to recover their estates from the Parliamentarian financial machine. Many of the widows professed the loyalty of their husbands, sons and themselves to Parliament in ways that were distinct from their male co-petitioners. A large number of petitions also utilised a common trope in the petitioning genre in general: language of distress and poverty which represented the petitioner as a helpless supplicant. Nonetheless, this did not necessarily mean that the petitioner was entirely powerless. Finally, many of the widows displayed an impressive knowledge of their entitlement in particular with regard to the processes of sequestration and of the law. This paper will examine each of these strategies in turn.

Rachel Weil has argued that the petitions of sequestered men to the Committee for Compounding are at one level 'a terrible source for talking about political allegiance' because they told the committee-men what they wanted to hear. Still, she argues that 'rather than bemoan the reliability of this evidence we might instead attempt to take advantage of it' ${ }^{26}$ Her study makes several interesting conclusions, namely that for those petitioners 'allegiance seems rarely to have been just a matter of inward belief ${ }^{27}$ Expressions of loyalty were often bound up with external circumstances, mainly financial, and professions of personal convictions of allegiance to either side were rare. The rhetoric of male petitioners in the files of the Committee for Sequestration adds weight to Weil's conclusion. In order to release their lands from confiscation many petitioners used their financial decisions as evidence of their affections. Thomas Blakistone for example stated that he had 'freely at severall times contributed to the Parliam[en]tes service, but not any thing to the other side'. ${ }^{28}$

Nevertheless, as Weil herself conceded, 'women will need to be considered separately' ${ }^{29}$ For wives and widows to express loyalty was perhaps even more complex than for male petitioners. Most of the widows who presented themselves at Westminster were there because of the actions of their husbands. Charlotte Stanley, the Countess of Derby, 
wrote in her petition in 1654 that 'shee humbly conceives is the only woman that ever was Sequestred for acting on that side to w[hi]ch her husband adhered'. ${ }^{30}$ Yet the sequestration process was in reality largely indiscriminate when it came to the allegiance of a wife and her husband. An analysis of the ways in which women expressed loyalty in their petitions leads to some interesting insights into the tactics of female petitioners that were distinct from their male co-petitioners. It also demonstrates that the study of records created by women can add greater nuance to any broader study of the period.

Some widows did use the language of financial or outward expressions of loyalty that closely echoed that of the male petitioners previously discussed. Several stated that they had 'paid all assesments, contributions and Twentie parts' as was required by Parliament. ${ }^{31}$ Others simply argued that they had 'in all things Conformed to the ordinances of Parliam[en]t ${ }^{32}$ For many women the surest demonstration of loyalty through outward action was in the profession that they had always lived in 'Parliament's quarters' (meaning those areas of the country directly under Parliament's control). ${ }^{33}$ Others took a more unambiguous approach to secure an appreciation of their allegiance. For example, Sarah Ellis claimed that she initially left Parliamentarian controlled Kent with her husband to go to the King's garrison at Oxford but that she returned soon after 'disliking the corse' there. ${ }^{34}$

Several women also claimed in their petitions some form of mitigating circumstance that forced them into an action that might be classed as disloyal to Parliament. At least three widows argued that they were forced to enter into the King's quarters to look after sick and ailing relatives: a story that while being plausible, must have also been intended to lend credibility to their actions by describing a duty that was expected of their gender. ${ }^{35}$ Wives would also seek to explain and defend their husband's actions. Some cited the threat of plunder as a reason for their husband initially going to war and one, Anne Presse, attempted to remove the stain of delinquency from her late husband's name by claiming that it was placed there 'without anie proofe of his taking up Armes for, or other Contribucion to the Kinges partie'. ${ }^{36}$ These narratives directly challenged the decision of the committees to class them and their husbands as delinquent in a way that was often bolder than their male counterparts. As Weil discussed, narratives of loyalty in the petitions of men were subtle by necessity. Accusing the committees of being wrong was dangerous and so statements were often ambiguous and more likely to express allegiance through outward conformity. ${ }^{37}$ Perhaps women were afforded more scope to defend their own and their husband's actions as their disloyalty to Parliament was unlikely to be expressed through combat. 
Finally, a small selection of widows did use phrases that would be more familiar to modern readers as expressions of loyalty. For example, one talked of being 'a wellwiller to the Parliament' and another that she 'hath ever stood well affected'. ${ }^{38}$ Some combined both inward and outward convictions seamlessly such as Lucy Pope, Countess of Downe, who wrote that she had 'never as yet given any aid or Assistance to the forces raised against the Parlyament' but also that she had not in 'any waies in her desires or Affecions adheared thereunto'. ${ }^{39}$ This sort of language corresponds with the vocabulary of political allegiance that the Parliamentarians chose to use and therefore does not necessarily mean that these women were genuine supporters of Parliament. ${ }^{40}$ Joan Heming, who claimed that her 'affections have always been very real to the Parliament and was very sollicitious $w[i]$ th her said husband to bee like affected', may have been using this narrative of allegiance in order to persuade the Committee. ${ }^{41}$ The language the petitioners chose to use must have been partly shaped by the expectations of the committees and, indeed, it was part of the skill of the petitioner to craft a petition in such a way. Some Royalist widow petitioners were able to engage with the narratives of loyalty that their male co-petitioners avoided and to turn that to their advantage.

Expressing allegiance in these turbulent times could be perilous and many widows did not even attempt it. Despite that, their petitions do still contain narratives that were intended to persuade the committees to hear their case favourably. One widow, Margery Morris, faced an especially difficult challenge in her suit because of the actions of her husband John Morris. He had fought first against the Irish confederates in 1642-3, returned to England to serve the King and then changed sides after Parliament captured Liverpool in 1644. Finally, he took Pontefract Castle for the Royalists in 1648, forcing the Parliamentary forces into a lengthy and costly siege. He was captured and sentenced to be hung, drawn and quartered in an 'unsoldierly trial and traitor's death'. ${ }^{4}$

Margery petitioned the Committee for Compounding at least three times between July 1650 and July 1651 asking for the sequestration on her portion of her husband's lands to be discharged. ${ }^{43}$ She wrote that her husband had been put to death 'in relac[i]on to what he had done as to the Kings service' but went no further into his motives or actions. Nevertheless, her petitions do not indicate an acceptance of her fate. She used the advice of legal counsel to assert that 'both dower and Jointure is reserved to the wife though the husband be attained of Treason' and used narratives of distress and poverty, with increasing persistence, in order to try to ignite sympathy for her plight amongst the Committee members. She asked that 
'though shee and her Children lost a husband and father yett they may not be deprived of all maintenance and subsistance' and that she was 'very sickly and weake' and unable to travel the 160 miles to London to the Committee. In her final petition to the committee she urgently requested a hearing for her case because she had 'three smale children' and did not have 'the wherew[i]th to feede them bread'. Three months later the sequestration on her estate was ordered to be discharged by the Committee on the grounds that when the deed granting her the inheritance was made her husband was in arms for Parliament in Ireland. ${ }^{44}$ Her persistent petitioning and use of persuasive narratives of entitlement and poverty may have been effective in bringing the case to a relatively speedy resolution and facilitated the surprising leniency of the Committee to the wife of a notorious multiple turncoat.

The petitions of other war widows frequently described hardship and distress as a result of the loss of husband and lands. Table 2 illustrates the status of the petitioners and shows that the widows who presented themselves were not all from the aristocracy or gentry. Certainly there was a large presence of such social groups, as is to be expected, and 64 of the widows identified themselves as such. Many left no identification of their status within their petition but where there is a record of their estates those had a value on average of just $£ 96$ per annum. This is far below the $£ 200$ a year 'cut off' supposedly set by Parliament. However, these figures could also reflect the undervaluing or concealment of lands by the widows in order to pay a lesser fine. ${ }^{45}$

Despite this spread of status it is not possible to make a clear correlation between the wealth of the petitioner and whether or not they pleaded poverty in their petition. Lady Elinor Hastings asked the Committee for Sequestration for some relief and that without it 'her and her three small children absolutely must starve'. ${ }^{46}$ Similarly, Lady Mary Howard pleaded that her and her children did not 'have any means allowed them to subsist on'. ${ }^{47}$ Ideas of what constituted poverty may have differed according to status and yet the language is similar to those widows who were more likely to be experiencing genuine poverty. One widow, whose husband was a labourer and whose lands only totalled two pounds a year, said that her children would soon be forced to go begging. ${ }^{48}$ Another, Mary Dalby, claimed that she and her children were 'wanting both food to eat and clothes to put on'. ${ }^{49}$

Male petitioners did occasionally refer to poverty and distress but often in the context of their wife and children being 'reddy to perish'. ${ }^{50}$ Widows, by contrast, could very usefully deploy common contemporary images of the poor and distressed widow which would have 
had universal appeal to the committee members. ${ }^{51}$ The Bible contains many references to the plight of widows and orphans and exhorts people to care for them such as that 'pure religion and undefiled before God and the Father is this, to visit the fatherless and widows in their affliction'. ${ }^{52}$ Accordingly, there are an overwhelming number of references to the petitioner as a 'poor widow' and requests that the committee be 'reflecting with the eye of compassion vpon the distresse of the Fatherless and widow'. ${ }^{53}$ It is possible that even genuinely poverty stricken widows may have been using elements of fiction for the sake of persuasion in the same way as widows of different social strata to them. Alison Thorne has argued that the deferential tone adopted by female petitioners in sources throughout the period 'may have been a subterfuge that masked their underlying combativeness'. ${ }^{54}$ It is difficult to separate genuine distress from clever rhetoric in these petitions but it does seem likely that a Christian call to look upon their plight with favour was a useful and probably successful literary device that was used very widely amongst the petitioners.

Those widows who did not employ language of poverty in their petitions were quite likely to use a different tactic: they reminded the committee of their own rights and the laws regarding sequestration and composition. Of course in a patriarchal society any woman openly questioning the actions of male political figures could be seen as dangerous and subversive. However in this instance, the defence of their family and their lands, widows were perhaps granted a certain license to act more independently within a forum that was occupied largely by men. Women in this period generally have been discovered to have been far more active participants in the legal system than has previously been stated. They appear to have been knowledgeable of the legal system and able to use it to their advantage. ${ }^{55}$ Since aristocratic women in particular would often have some measure of control of property this was an area in which women experienced more agency than they might otherwise have possessed.

Many Royalist widows were able to utilise knowledge of the various Ordinances and processes related to sequestration. For example, Dorothy Hartborne asked to be granted one third of her husband's estate for her maintenance and reminded the Committee for Compounding that she was due this 'according the the laws and statutes of this nation, the orders and acts of this present Parliament and your honours [i.e. the Committee's] own rules'. ${ }^{56}$ Another protested that she 'knoweth not any thing in law or equity, which shee could not enjoy the said Estate'. ${ }^{57}$ Some widows went further and complained that there had been some malpractice on behalf of the county committee who had sequestered their estates. One 
argued that the original certificate which had entailed her lands to be sequestered was 'uncertain and dubious', while Elizabeth Curle suggested that her estate was only sequestered on a clerk's mistake. ${ }^{58}$ Maybe she found it easier to question the administration rather than the whole system: a type of small scale opposition that was common in early modern England. It is likely that some knowledge of the law came from the legal counsel that women of higher status had access to. Elizabeth Hamilton, for example, based the arguments in her petition on the instruction of her 'learned Councell'. ${ }^{59}$ However, petitioners rarely explicitly referred to advice they received in this way. This may have been because it was considered more effective if the petitioner came across as the main agent behind the petition.

Finally, this paper has largely concerned itself with the content of the petitions but there remains something to be said about the relative 'success' of their endeavours. Table 3 illustrates the outcomes of the cases based on information contained within the files of the Committees for Compounding, Sequestration and Advance of Money. Unfortunately for a considerable portion of widows there are no documents which indicate the result of their suits. ${ }^{60}$ The evidence there is suggests that the Committee for Compounding generally did grant the request of the widow to pay a fee to regain their lands and would occasionally allow the sequestration to be removed entirely from the lands. In fact, only fifteen had their request either to compound or for the sequestration to be removed denied.

Thus it does appear that those administering the sequestration process had moved away from the earliest guidelines of 1643 to punish the 'notorious delinquents' who were deemed responsible for the war to become largely an administrative and financial operation during the Interregnum. The healing and settling of the nation was now a priority if the country was to recover from the effects of Civil War. David Smith and Patrick Little have argued that the 1650s saw 'the gradual alienation of the army, and the growing alliance between the Presbyterians and the civilian court'. ${ }^{61}$ That could be part of the reason why 95 of the 167 widows were able to access their lands again as a result of their petitions. As previously seen Margery Morris, whose husband was executed for his treachery, had her lands released. The committee-men might have also rewarded the honesty of Mary Robinson who initially claimed to be 'ignorant of the cause' of her sequestration but did admit in a later petition that she had sent her son to fight for the king furnished with a horse. She stressed that she was 'hartily sorry' for this offense and was allowed her lands back for a small fine. ${ }^{62}$ 
Nonetheless, there were a handful of women who were never granted their lands back. Mary Crompton had in her petition maintained that her estate was sequestered upon some 'pretence' of delinquency but the Committee for Compounding discovered that she had kept a garrison against Parliament at Dawley Castle in Shropshire and it was duly ordered to be continued. ${ }^{63}$ Elizabeth Rutter's estate had been sequestered in 1646 on evidence that her husband had been in arms at the Royalist garrison at Chester. She sent at least ten petitions between 1646 and 1654 to the Committees for Sequestration, Compounding, the Houses of Parliament and finally Oliver Cromwell himself to try to regain her lands. ${ }^{64}$ On each occasion her plea was denied. ${ }^{65}$ This continued rejection, despite Elizabeth's heartfelt pleas, may have been related to the report of the county committee of Chester taken in 1646 and resubmitted in 1651. They had examined a local woman, Mary Harefinch, who claimed to have seen how Elizabeth, on learning of the death of many hundreds of Parliamentarians in a nearby battle, had 'clapped her hands for Joy and thanked god for it and said shee hoped that would be the end of them all that fought against the King, ${ }^{66}$ Even though this account may reflect certain prejudice on the part of the witness it does show how a regime that was increasingly concerned with the healing of old wounds was still afraid to allow such sentiments to go unpunished. Ultimately, these cases demonstrate that there was indeed a limit to the persuasive power of the petition.

This paper has shown that there is value in studying the narratives contained within the petitions of Royalist widows. They add to the work already undertaken on the Committee for Compounding and demonstrate that female petitioners used both similar and distinctive tactics to men. Therefore these petitions can enrich any study of loyalty and allegiance during the period. They also tell us about the complexity of the position of wives in relation to the action of their husbands. One widow had her case discharged because her Royalist husband had died but the rest were implicated by the actions of their husbands when they inherited their lands. ${ }^{67}$ It could work in the reverse as one husband used his marriage to a 'well affected' wife to maintain his loyalty to Parliament. ${ }^{68}$ It seems that the committees, and even society at large, were unsure about how closely the actions and thoughts of husbands and wives could be bound to one another. For wives of Royalist men that was a particularly pertinent question but many used the independence that widowhood had created to construct petitions that protested their loyalty and right to their lands. They fashioned themselves as supplicants who came humbly to the arena of politics and yet in doing so acted as guardians 
of their estates. Many would use the petition with success to survive life on the home front of Civil War society.

\section{Notes}

\footnotetext{
${ }^{1}$ Ian Gentles (2007) The English Revolution and the Wars in the Three Kingdoms, 1638-1652 (Harlow: Pearson), Table 15.1, p. 436; for alternative estimates see also Charles Carlton (1992) Going to the Wars: The Experience of the English Civil Wars (London: Routledge), pp. 273-277.

${ }^{2}$ Karen Hunt (2010) The Politics of Food and Women's Neighborhood Activism in First World War Britain, International Labor and Working-Class History, 77, p. 1.

${ }^{3}$ Barbara Donagan (2008) War in England 1642-1659 (Oxford: Oxford University Press), p. 11; Megan J. McClintock (1996) Civil War Pensions and the Reconstruction of Union Families, The Journal of American History, 83(2), p. 458.

${ }^{4}$ Rachel Weil (2006) Thinking About Allegiance in the English Civil War, History Workshop Journal, 61, pp. 183-191.

${ }^{5}$ Sequestration Committee, The National Archives (TNA), State Papers (SP) 20; Committee for Compounding with Delinquents, TNA, SP 23.

${ }^{6}$ Mary Anne Everett Green (1889-1893) Calendar of the Proceedings of the Committee for Compounding with Delinquents, 1643-1660 (London: HMSO) pp. xii-xiii.

${ }^{7}$ Information of Constance Stringer, 25 February 1561, TNA, SP 23/120 p. 33; Deposition of Mary Window, 13 October 1659, TNA, SP 23/263 p. 36.

${ }^{8}$ March 1643: An Ordinance for sequestring notorious Delinquents Estates, in C. H. Firth and R. S. Rait (Eds) (1911) Acts and Ordinances of the Interregnum, 1642-1660 (London: HMSO), pp. 106-117.

${ }^{9}$ Patricia Crawford (2001) 'The poorest she': Women and citizenship in early modern England, in Michael Mendle (Ed) The Putney Debates of 1647: the army, the levellers, and the English state (Cambridge: Cambridge University Press), pp. 197-218; Barbara J. Harris (1990) Women and Politics in early Tudor England, The Historical Journal, 33(2), pp. 259-281; Ann Hughes (1995) Gender and Politics in Leveller Literature, in Susan Dwyer Amussen \& Mark Kishlansky (Eds) Political Culture and Cultural Politics in Early Modern England: essays presented to David Underdown (Manchester: Manchester University Press), pp. 162-88.

${ }^{10}$ Tim Stretton (1998) Women Waging Law in Elizabethan England (Cambridge: Cambridge University Press), p. 216.

${ }^{11}$ Alison Thorne (2006) Women's Petitionary Letters and Early Seventeenth-Century Treason Trials, Women's Writing, 13(1), p. 23.

${ }^{12}$ Alison Thorne (2013) Narratives of Female Suffering in the Petitionary Literature of Civil War Period and its Aftermath, Literature Compass, 10(2), p. 135.

${ }^{13}$ Petition of Elizabeth Lilburne, 21 January 1659, TNA, SP 18/200 p. 107.

${ }^{14}$ Ann Hughes (1997) Women, Men and Politics in the English Civil War (Keele Pamphlets: Keele University), p. 174.

${ }^{15}$ Ann Marie McIntee (1991) 'The [un]civill-sisterhood of oranges and lemons': Female petitioners and demonstrators, 1642-53, Prose Studies, 14, pp. 92-111.

${ }^{16}$ The Committee for the Advance of Money, TNA, SP 19.

${ }_{17}^{17}$ Petition of Elizabeth Cotton, 18 March 1646, TNA, SP 20/12/32 p. 94.

${ }^{18}$ April 1650: An Act impowering several Comissioners to put in Execution all and every the Powers and Authorities heretofore given to the Commissioners for compounding with Delinquents, in Firth and Rait (Eds), Acts and Ordinances, pp. 382-383.

${ }^{19}$ James Daybell (2012) The Material Letter in Early Modern England: manuscript letters and the culture and practices of letter-writing, 1512-1635 (Basingstoke: Palgrave Macmillan), pp. 73-74.

${ }^{20}$ David Cressy (1980) Literacy and the Social Order (Cambridge: Cambridge University Press), p. 145.

${ }^{21}$ Ibid., pp. 118-119, 137.

${ }^{22}$ Jacqueline Eales (2013) To Booke and Pen: Women, education and literacy in Tudor and Stuart England, The Historian, 119, pp. 24-29.

${ }^{23}$ Natalie Zemon Davis (1987) Fiction in the Archives: pardon tales and their tellers in sixteenth-century France (Cambridge: Polity), pp. 2-3.

${ }^{24}$ Stretton, Women Waging Law, pp. 18-19.

${ }^{25}$ Ann Hughes (1986) Parliamentary Tyranny? Indemnity Proceedings and the Impact of the Civil War: A case study from Warwickshire, Midland History, 11(1), pp. 49-78.

${ }^{26}$ Weil, Thinking about Allegiance, p. 185.
} 
${ }^{27}$ Ibid., p. 190.

${ }^{28}$ Petition of Thomas Blakistone, 4 October 1644, TNA, SP 20/10/3 f. 8r; see also Petition of Sir Francis

Dowse, 30 December 1645, TNA, SP 20/11/14 f. 69r.

${ }^{29}$ Weil, Thinking about Allegiance, p. 190.

${ }^{30}$ Petition of Charlotte Stanley, 14 July 1654, TNA, SP 23/230 p. 55.

${ }^{31}$ Petition of Rebecca Harvey, 10 March 1646, TNA, SP 23/180 p. 585; Petition of Judith Clarke, 20 October 1645, TNA, SP 23/182 p. 74.

${ }^{32}$ Petition of Alice Estcott, 24 March 1646, TNA, SP 23/180 p. 246.

${ }^{33}$ Petition of Anne Denham, 25 November 1645, TNA, SP 20/10/61 f. 158r.

${ }^{34}$ Petition of Sarah Ellis, 12 December 1646, TNA, SP 23/208 p. 374.

${ }^{35}$ Petition of Sarah Cox, 24 January 1646, TNA, SP 23/177 p. 665; Petition of Rebecca Harvey, 10 March 1646, TNA, SP 23/180 p. 585; Petition of Elizabeth Rogers, 20 June 1646, TNA, SP 23/189, p. 27.

${ }^{36}$ Petition of Anne Presse, 10 March 1646, TNA, SP 23/177 p. 405.

${ }^{37}$ Weil, Thinking about Allegiance, pp. 186-188.

${ }^{38}$ Petition of Ellen Byrom, 9 April 1647, TNA, SP 20/13/8 f. 61r; Petition of Margaret Houghton, 10 June 1646 , TNA, SP 20/12/41 f. 114r.

${ }^{39}$ Petition of Lucy Pope, 3 September 1645, TNA, SP 20/11/23 f. 105r.

${ }^{40}$ Weil, Thinking about Allegiance, p. 184.

${ }^{41}$ Petition of Joan Heming, 18 May 1649, TNA, SP 23/212 p. 182.

${ }^{42}$ Andrew Hopper (2012) Turncoats and Renegadoes: changing sides during the English Civil War (Oxford: Oxford University Press), p. 194.

${ }^{43}$ Petitions of Margery Morris, July 1650-1651, TNA, SP 23/101 pp. 665, 682, 664.

${ }^{44}$ Order of the Committee for Compounding, 30 October 1651, TNA, SP 23/15 p. 67.

${ }^{45}$ Order of the Committee for the Advance of Money, 29 July 1656, TNA, SP 19/120 pp. 109-110.

${ }^{46}$ Petition of Elinor Hastings, [1645], TNA, SP 20/10/37 f. 99r.

${ }^{47}$ Petition of Mary Howard, 9 December 1647, TNA, SP 20/13/25 f. 119r.

${ }^{48}$ Petition of Catherine Bolton, 12 June 1655, TNA, SP 23/130 p. 623.

${ }^{49}$ Petition of Mary Dalby, 28 May 1646, TNA, SP 23/79 p. 615.

${ }^{50}$ Petition of Thomas Haywood, TNA, SP 20/12/18, f. 132r.

51 Thorne, Women's petitionary letters, p. 29.

52 (1611) The Holy Bible, King James Version, James 1:27.

${ }^{53}$ Petition of Elizabeth Higham, 24 July 1649, TNA, SP 23/216 p. 870; Petition of Bridget Chorley, 17 October 1650, TNA, SP 23/74 p. 436.

${ }^{54}$ Thorne, Narratives of female suffering, p. 135.

${ }^{55}$ Stretton, Women Waging Law, p. 216; Garthine Walker \& Jennifer Kermode (1994) Introduction, in Garthine Walker \& Jennifer Kermode (Eds) Women, Crime and the Courts in Early Modern England (London: UCL Press), pp. 1-25.

${ }^{56}$ Petition of Dorothy Hartborne, 14 May 1651, TNA, SP 23/91 p. 220.

${ }^{57}$ Petition of Alice Grenehalgh, 10 August 1653, TNA, SP 23/88 p. 628.

${ }^{58}$ Petition of Elizabeth Cotton, 18 March 1646, TNA, SP 20/12/32 f. 94r; Petition of Elizabeth Curle, 24 May 1655, TNA, SP 23/79 p. 68.

${ }_{59}$ Petition of Elizabeth Hamilton, 21 July 1653, TNA, SP 19/12 pp. 398-399.

${ }^{60}$ When the records of the County Sequestration Committees (TNA, SP 28/205-218) are fully catalogued that picture may be more complete.

${ }^{61}$ David L. Smith \& Patrick Little (2007) Parliaments and Politics during the Cromwellian Protectorate (Cambridge: Cambridge University Press), p. 125.

${ }^{62}$ Petitions of Mary Robinson, March-July 1646, TNA, SP 23/184 pp. 916, 918.

${ }^{63}$ Petition of Mary Crompton, 28 September 1653, TNA, SP 23/77 p. 579; Committee for Compounding case file, 22 February 1654, TNA, SP 23/77 p. 570.

${ }^{64}$ Petitions of Elizabeth Rutter, April 1646-March 1654, TNA, SP 23/114 pp. 1213, 1241, 1217, 1232, 1246, 1209, 1199; TNA, SP 23/236 p. 109; TNA, SP 25/75 p. 527; TNA, SP 25/92 p. 97.

${ }^{65}$ Order of the Sequestration Committee, 27 June 1649, TNA, SP 20/8 f. 115r; House of Commons Journal Volume 6: 25 March 1650 (London: HMSO); Order of the Committee for Compounding, 16 March 1650, TNA, SP 23/8 p. 6; Order of the Council of State, 2 January 1656, TNA, SP 25/92 p. 97.

${ }^{66}$ Examination of Mary Harefinch, 25 April 1646, TNA, SP 23/148 p. 97.

${ }^{67}$ Report of John Bradshaw, 7 January 1647, TNA, SP 20/12/2 f. 3r.

${ }^{68}$ Petition of Edward Panton, 3 January 1646, TNA, SP 23/110 p. 816. 
Table 1. Regional spread of Royalist widows petitioning the Committees for Sequestration, Compounding and Advance of Money

\begin{tabular}{|l|l|}
\hline Region & Total \\
\hline London & 12 \\
\hline North & 51 \\
\hline East Midlands & 12 \\
\hline West Midlands & 21 \\
\hline South-West & 19 \\
\hline East & 9 \\
\hline South & 7 \\
\hline South-East & 26 \\
\hline Wales & 3 \\
\hline Scotland & 2 \\
\hline Unidentified & 5 \\
\hline & 167 \\
\hline
\end{tabular}

Source: TNA, SP 19, 20, 23. 
Table 2. Status of Royalist widows petitioning the Committees for Sequestration, Compounding and Advance of Money

\begin{tabular}{|l|l|}
\hline Status & Total \\
\hline Peer & 25 \\
\hline Baronet & 2 \\
\hline Knight & 12 \\
\hline Esquire & 15 \\
\hline Gentleman & 10 \\
\hline Merchant & 3 \\
\hline Yeoman & 1 \\
\hline Other & 9 \\
\hline No indication & 90 \\
\hline & 167 \\
\hline
\end{tabular}

Source: TNA, SP 19, 20, 23. 
Table 3. Outcome of the cases of Royalist widows at the Committees for Sequestration, Compounding and Advance of Money

\begin{tabular}{|l|l|}
\hline Result & Total \\
\hline Composition allowed & 50 \\
\hline Sequestration removed & 25 \\
\hline Jointure granted & 20 \\
\hline Died before resolution & 4 \\
\hline Request not granted & 15 \\
\hline Unclear & 53 \\
\hline & 167 \\
\hline
\end{tabular}

Source: TNA, SP 19, 20, 23. 
Figure 1. Instances of Royalist widows petitioning the Committees for Sequestration, Compounding and Advance of Money

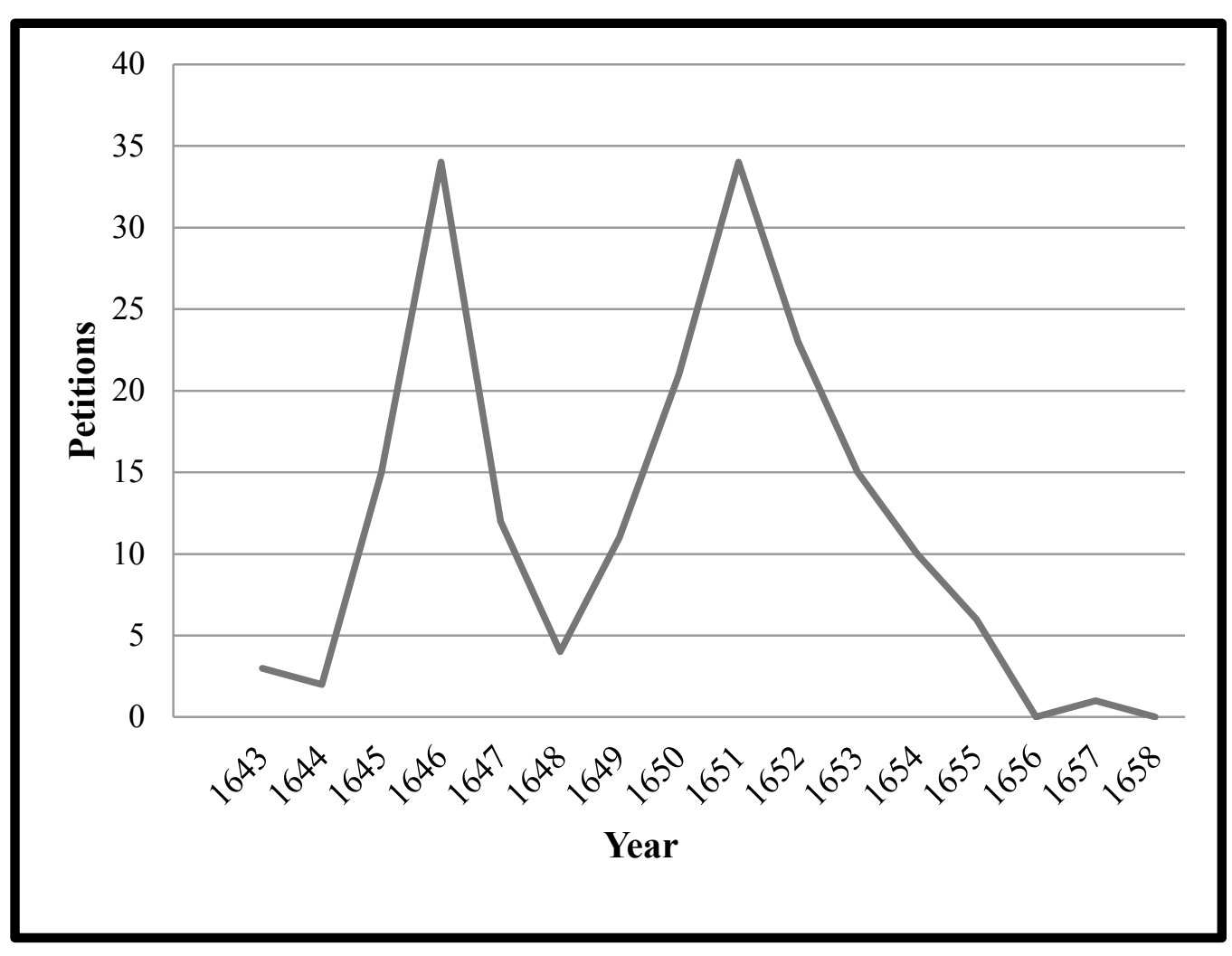

Source: TNA, SP 19, 20, 23. 